OPTIMUM. STUDIA EKONOMICZNE NR 3 (69) 2014

\author{
Piotr P. MAŁECKI, Maria URBANIEC ${ }^{1}$
}

\title{
KOSZTY ŚRODOWISKOWE W POLSCE W UJĘCIU TEORETYCZNYM I STATYSTYCZNYM
}

\begin{abstract}
Streszczenie
Koszty środowiskowe są ogólnym pojęciem dla różnych kosztów związanych z działaniami na rzecz ochrony środowiska i z oddziaływaniem na środowisko. W praktyce są one ujmowane w rachunku kosztów funkcjonowania przedsiębiorstw w sposób cząstkowy bądź są zawarte w pozycjach zagregowanych. Dotychczas nie opracowano jeszcze ujednoliconych standardów w zakresie: zasad pomiaru, dokumentacji, ewidencji i rozliczania wydatków środowiskowych w przedsiębiorstwie. Obowiązki sprawozdawcze przedsiębiorców, obejmujące ochronę środowiska, regulują liczne akty prawne. W odniesieniu do kosztów środowiskowych brak jest kompleksowych badań określających ich wysokość i strukturę w całej gospodarce narodowej. Główny Urząd Statystyczny prowadzi w tym zakresie jedynie okresowe i wycinkowe badania, bazując na danych dostarczanych przez nieznaczną liczbę przedsiębiorstw. Niebawem regulacje prawne Unii Europejskiej nałożą na państwa członkowskie obowiązek sporządzania obszernych sprawozdań dotyczaccych wielkości ponoszonych kosztów środowiskowych, zgodnie z metodyką Eurostatu. Aktualnie trwaja prace nad uchwaleniem aktu prawnego, przygotowanego już w tym zakresie. Celem artykułu jest: rozwinięcie zagadnienia kosztów środowiskowych, ponoszonych przez przedsiębiorstwa i inne jednostki, analiza dotychczasowych badań określających ich wysokość w gospodarce narodowej, jak również próba stworzenia metodologicznych podstaw szerokiej sprawozdawczości dotyczącej kosztów środowiskowych w związku z nowymi wymogami nałożonymi przez Unię Europejską.
\end{abstract}

Słowa kluczowe: koszty środowiskowe, nakłady na ochronę środowiska, koszty bieżące ochrony środowiska, sprawozdawczość statystyczna, wymogi Eurostatu

\section{ENVIRONMENTAL COSTS IN POLAND: A THEORETICAL AND STATISTICAL APPROACH}

\section{Summary}

Environmental costs are a general term for the various costs associated with actions to protect the environment and with impacts on the environment. In practice, they are recognized in the cost accounts of companies in a partial manner, or are included in the aggregated positions. So far no uniform standards have been established for the principles of measurement, documentation, registration and accounting for environmental costs in the enterprises. The reporting obligations of entrepreneurs in the field of environmental protection are governed by numerous legal provisions. With regard to environmental costs, there is no comprehensive test to determine their amount and structure in the national economy. The Central Statistical Office conducts only periodic and fragmentary studies in this field, based on data provided by a small number

1 dr hab. Piotr P. Małecki - Wydział Finansów, Uniwersytet Ekonomiczny w Krakowie; e-mail: maleckip@uek.krakow.pl; dr Maria Urbaniec - Wydział Ekonomii i Stosunków Międzynarodowych, Uniwersytet Ekonomicznyw Krakowie; e-mail: maria.urbaniec@uek.krakow.pl. 
of companies. EU regulations will soon impose on the Member States the obligation to draw up extended reports on the size of environmental costs, according to the Eurostat methodology. Currently, a relevant legal act is being drafted. The aims of this article are to discuss the current state in the field of environmental costs incurred by enterprises and other entities, to analyse the existing research into their amount in the national economy, as well as to make an attempt at the creation of a methodological basis for broad reporting of environmental costs in line with the new requirements imposed by the EU.

Key words: environmental costs, outlays on environmental protection, current costs of environmental protection, statistical reporting, Eurostat requirements

\section{Wstęp}

Złożoność ochrony środowiska polega na podejmowaniu lub zaniechaniu działań umożliwiających zachowanie lub przywracanie równowagi przyrodniczej, a zwłaszcza racjonalne kształtowanie środowiska i gospodarowanie jego zasobami zgodnie $\mathrm{z}$ zasada zrównoważonego rozwoju, a także przeciwdziałanie zanieczyszczeniom i przywracanie elementów przyrodniczych do właściwego stanu. Szczególną rolę w tym procesie odgrywają przedsiębiorstwa, które coraz częściej dostrzegają z tym związane wyzwania i dazża do prowadzenia działalności według nowoczesnych trendów rozwoju społecznogospodarczego oraz w większym stopniu podejmuja zintegrowane działania na rzecz ochrony środowiska. Ograniczona dostępność zasobów naturalnych i niewielka zdolność elementów środowiska naturalnego (takich jak: woda, gleba i powietrze) do absorpcji szkodliwych pozostałości pochodzących z produkcji i konsumpcji stawia nowe wyzwania wobec zarządzania każdym przedsiębiorstwem.

Podejmując działania na rzecz ochrony środowiska, przedsiębiorstwa i inne podmioty, korzystające z jego zasobów, zmierzają przede wszystkim do optymalizacji kosztów środowiskowych, co wynika z możliwości redukcji kosztów zanieczyszczania środowiska i kosztów ochrony środowiska. Koszty środowiskowe są ogólnym pojęciem dla różnych kosztów zwiazzanych z działaniami na rzecz ochrony środowiska i z oddziaływaniem na środowisko. W praktyce są one ujmowane w rachunku kosztów funkcjonowania podmiotów korzystających ze środowiska w sposób cząstkowy bądź są zawarte w pozycjach zagregowanych. Dotychczas nie opracowano jeszcze ujednoliconych standardów w zakresie: zasad pomiaru, dokumentacji, ewidencji i rozliczania wydatków środowiskowych. Niemniej jednak obowiazki sprawozdawcze przedsiębiorstw $i$ innych podmiotów, obejmujące ochronę środowiska, regulują liczne akty prawne - przede wszystkim Ustawa Prawo ochrony środoniska [Ustawa..., 2001].

Ustawy i inne dokumenty regulują w tym zakresie jedynie ogólne zasady postępowania podmiotów korzystających ze środowiska i powodują w konsekwencji ponoszenie przez te podmioty różnego rodzaju kosztów (wydatków). Natomiast w odniesieniu do kosztów środowiskowych brak jest kompleksowych badań określających ich wysokość i strukturę w całej gospodarce narodowej. Główny Urząd Statystyczny (GUS) prowadzi w tym zakresie jedynie okresowe i wycinkowe badania, bazując na danych dostarczanych przez nieznaczną liczbę podmiotów. W Polsce kompetencje zbierania i przekazywania poszczególnych danych statystycznych reguluje, corocznie publikowany, program badań statystycznych statystyki publicznej. Nieba- 
wem regulacje prawne Unii Europejskiej (UE) nałożą na państwa członkowskie obowiązek sporządzania obszernych sprawozdań dotyczących wielkości ponoszonych kosztów środowiskowych, zgodnie z metodyką Eurostatu. Aktualnie trwaja prace nad uchwaleniem aktu prawnego przygotowanego już w tym zakresie.

Celem artykułu jest: rozwinięcie zagadnienia kosztów środowiskowych, ponoszonych w głównej mierze przez przedsiębiorstwa, analiza dotychczasowych badań określających ich wysokość w gospodarce narodowej, jak również próba stworzenia metodologicznych podstaw szerokiej sprawozdawczości dotyczącej kosztów środowiskowych w związku z nowymi wymogami nałożonymi przez Unię Europejską.

W artykule przedstawiono istotę kosztów środowiskowych. Dokonano także analizy, obecnie obowiązującej w Polsce, sprawozdawczości statystycznej w zakresie kosztów środowiskowych, jak też oceny kształtowania się wielkości tych kosztów w całej gospodarce narodowej w ostatnich kilku latach. W końcowej części artykułu opisano zadania, które ma przed sobą system sprawozdawczości statystycznej wobec nowych wymogów Eurostatu.

\section{Istota i rodzaje kosztów środowiskowych}

Proces ochrony środowiska obejmuje: wykorzystanie zasobów środowiska, zapobieganie powstawaniu zagrożeń (działalność prewencyjna), ograniczanie emisji zagrożeń (działalność redukcyjna), naprawę zniszczeń (restytucję) oraz zarządzanie tą działalnością. Działania na rzecz ochrony środowiska wymagają: zużycia zasobów rzeczowych i finansowych, zasobów pracy, wykorzystania usług obcych, w wyniku czego powstają odpowiednie rezultaty rzeczowe oraz rezultaty finansowe. Zużycie zasobów może być zmierzone ilościowo (np.: w metrach, kilogramach czy sztukach) oraz wartościowo (np.: za pośrednictwem kosztów), [Famielec, Broniewicz, 2006]. W odniesieniu do ochrony środowiska ma zastosowanie pojęcie kosztów, ze względu na występowanie nakładów czysto pieniężnych.

Koszty definiuje się w literaturze jako wyrażone w pieniądzu zasoby (dobra i usługi) użyte w celu osiagnięcia bieżących lub przyszłych korzyści. Zgodnie z ustawą o rachunkowości, przez koszty rozumie się: uprawdopodobnione zmmiejszenia w okresie sprawozdawczym korzyśsi ekonomicznych, o wiarygodnie okereślonej wartości, w formie żmniejszenia wartości aketywów albo zuiekeszenia wartości zobowiazań i rezern, które doprowadza do zmniejszenia kapitatu wtasnego lub zwiększenia jego niedoboru w inny sposób niž wy cofanie środków przez udziałowców lub wlaścicieli [Ustawa z. dnia 29 września 1994..., 2013].

Odnosząc tą definicję do ochrony środowiska, przez pojęcie kosztów środowiskowych można rozumieć wyrażone w pieniądzu zużycie zasobów (dóbr i usług) w celu osiagnięcia bieżących lub przyszłych korzyści związanych z ochroną środowiska, która pozwoli używać zasoby środowiska dziś i w przyszłości, zapewniając w ten sposób możliwość prowadzenia działalności gospodarczej bez ograniczenia czasowego [Stępień, 2003, s. 238]. Koszty środowiskowe stanowią zatem wyrażone w pieniądzu świadome zużycie zasobów rzeczowych, pracy i usług obcych w celu zachowania równowagi środowiskowej. Są to więc koszty przeciwdziałające faktycznemu lub poten- 
cjalnemu pogorszeniu walorów przyrodniczych, spowodowanemu działalnościa gospodarcza, jak również - pozagospodarczą aktywnością człowieka.

W literaturze występuje także pojęcie kosztów ochrony środowiska oraz kosztów ekonomicznych ochrony środowiska [Hellich, Klonowska, 2007, s. 171]. Koszty ochrony środowiska obejmują ekonomiczne i społeczne koszty podjęte w celu realizacji przedsięwzięć ochrony lub kształtowania środowiska. Natomiast koszty ekonomiczne ochrony środowiska są definiowane jako nakłady pracy żywej i uprzedmiotowionej, zużywane na wszelkiego rodzaju przedsięwzięcia ochrony środowiska. Dzielone są one na:

- nakłady inwestycyjne, czyli nakłady na: budowę, instalowanie, rekonstrukcję i modernizację urządzeń, instalacji, obiektów ochrony środowiska lub związane $\mathrm{z}$ wprowadzeniem zmian w procesach technologicznych na technikę korzystniejszą dla środowiska;

- $\quad$ koszty eksploatacyjne, czyli nieinwestycyjne koszty związane z przedsięwzięciami ochrony środowiska, w tym zwłaszcza: koszty amortyzacji, konserwacji i remontów, zasilania w energię, obsługi urządzeń ochrony środowiska, a także analogiczne koszty dodatkowe łączące się z funkcjonowaniem techniki korzystniejszej dla środowiska oraz opłaty za korzystanie ze środowiska (opłaty emisyjne).

Koszty środowiskowe są zatem ogólnym pojęciem dla różnych kosztów wiążących się z: zarządzaniem środowiskiem, działaniami na rzecz ochrony środowiska i oddziaływaniami na środowisko. Koszty te wynikają z różnych koncepcji kosztów, obszarów zastosowania i celów [Leitfaden Betriebliches Umweltkostenmanagement, 2003, s. 45].

Niekiedy w literaturze przedmiotu, a przede wszystkim w praktyce gospodarczej, pojawia się termin wydatki na ochrone środowiska jako synonim kosztów środowiskowych. Stoi to w sprzeczności z księgowym rozumieniem obu tych kategorii, mimo istniejących, niewątpliwie, bliskich relacji między nimi [Micherda, 2002, s. 131]. Jednakże: w odniesieniu do rachunkowości środowiskowej na szczeblu przedsiebiorstwa czesto jest u̇zwane pojecie kosz̨tu, a termin wydatki jest stosowany w kontekśsie makroekonomicznym. Z koncepcyjnego punktu widzenia

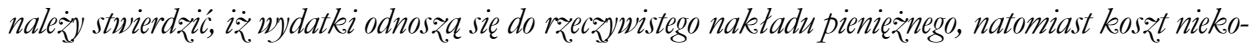
niecznie jest zwiazany z.reczymistym nakładem [Environmental expenditure statistics, 2005, s. 137].

Koszty środowiskowe mają także odniesienie do kosztów korzystania ze środowiska i wprowadzania w nim zmian. Są to koszty związane z korzystaniem z zasobów środowiska i obejmuja [Hellich, Klonowska, 2007, s. 172]:

- opłaty za emisję zanieczyszczeń powietrza;

- opłaty za umieszczanie odpadów na składowisku odpadów;

- opłaty za pobór i korzystanie z wód, z urządzeń wodnych i wprowadzanie ścieków do wód lub ziemi;

- opłaty za wydobywanie kopalin;

- $\quad$ inne opłaty i podatki ekologiczne.

Zasady naliczania i uiszczania opłat określają m.in. ustawa Prawo ochrony środowisk.a oraz wynikające z niej akty wykonawcze.

W praktyce często są dyskutowane różnice między kosztami a nakładami ponoszonymi na ochronę środowiska. W zależności od aspektów decyzyjnych raz moga to być istotne nakłady na inwestycje służące ochronie środowiska, innym razem koszty amortyzacji aktywów trwałych służących ochronie środowiska. 
Według Głównego Urzędu Statystycznego, całkowite nakłady na ochronę środowiska stanowią sumę nakładów na środki trwałe służące ochronie środowiska i kosztów bieżących [Ochrona środowiska..., 2011, s. 391]. Ponadto, Główny Urząd Statystyczny rozróżnia także nakłady inwestycyjne na ochronę środowiska w przedsiębiorstwie, które obejmują nakłady na: budowę, instalowanie, rekonstrukcję i modernizację urządzeń, instalacji, obiektów ochrony środowiska lub związane z wprowadzeniem zmian w procesach technologicznych na technikę korzystniejszą dla środowiska. Nakłady inwestycyjne zawierają nakłady na środki trwałe oraz pozostałe nakłady.

Podsumowując, należy stwierdzić, iż w każdym przedsiębiorstwie występują różne koszty ochrony i korzystania ze środowiska, które wchodzą w skład ogólnych kosztów firmy i są w większości przypadków niezidentyfikowane. Koszty środowiskowe, zwłaszcza koszty bieżące, są często rejestrowane w kilku miejscach powstawania kosztów, co stwarza wattpliwości pod względem prawidłowości zasad podziału na miejsca i rodzaje kosztów. Aktualnie, koszty środowiskowe w praktyce są ujmowane w rachunku kosztów funkcjonowania przedsiębiorstw w sposób cząstkowy i nie zawsze odzwierciedlający ich rangę. Główny problem polega tu na braku odpowiedniej ewidencji, jak również analizie tych kosztów oraz opracowaniu wniosków wspomagających podejmowanie istotnych działań i ustalenie kierunku rozwoju firmy. Obecny stan sprawozdawczości nie ułatwia tego typu analiz, co szczegółowo przedstawiono w kolejnym rozdziale.

\section{Sprawozdawczość statystyczna w zakresie kosztów środowiskowych - stan obecny}

Przez pojęcie sprawozdawczości statystycznej, dotyczącej kosztów środowiskowych, należy rozumieć procedurę zbierania, a następnie prezentowania danych z tego zakresu. Procedurę gromadzenia danych można podzielić na dwie części. W skład pierwszej z nich wchodzi zbieranie danych o kosztach bieżących, poniesionych na ochronę środowiska. Natomiast druga obejmuje gromadzenie bardziej szczegółowych informacji na temat wielkości kategorii zaliczanych do, określonych i zdefiniowanych wcześniej, kosztów środowiskowych.

Zbieranie danych sprawozdawczych, w tym także związanych z kosztami środowiskowymi, prowadzone jest na podstawie systemu zbierania danych, określanego jako „Program badań statystyki publicznej”. Jego prawnym uregulowaniem jest, wydawane corocznie, stosowne rozporządzenie Rady Ministrów w sprawie programu badań statystycznych statystyki publicznej wraz ze szczegółowym załącznikiem pt.: Program badań statystycznych statystyki publicznej na rok... Jest to konsekwencja zapisów Ustany o statystyce publicznej [Ustawa z dnia 29 czerwca 1995 roku..., 1995]. Ponadto, corocznie jest wydawane odpowiednie rozporządzenie Prezesa Rady Ministrów, wyznaczające wzory obowiązujących formularzy sprawozdawczych i objaśnienia co do sposobu ich wypełniania. W zakresie odnoszącym się do kosztów środowiskowych obowiązują jednocześnie inne, istotne sprawozdania sporządzane poza programem badań statystyki publicznej, tj. w ramach wewnętrznych administracyjnych systemów infor- 
macyjnych różnych instytucji, jak na przykład Narodowy Fundusz Ochrony Środowiska i Gospodarki Wodnej czy Ministerstwo Środowiska.

Badania obejmujące koszty środowiskowe sa przeprowadzane przez Ministerstwo Środowiska w ujęciu sektorowym, według rodzajów kosztów i elementów środowiska. Metodyka prowadzonych badań jest oparta na, wdrażanym przez Unię Europejska (Eurostat), Europejskim Systemie Zbierania Informacji Ekonomicznej dotyczacej Ochrony Środowiska (SERIEE) i jednocześnie na wymogach wspólnego kwestionariusza OECD i Eurostatu (EPER - Joint OECD/Eurostat Questionnaire - Environmental Protection Expenditure and Revenues). Badania sa prowadzone metodą reprezentacyjną w cyklu trzyletnim. W okresach między badaniami dane o kosztach środowiskowych są określane metodą szacunkową.

Podstawowym formularzem sprawozdawczym, wiążącym się z kosztami środowiskowymi, jest „Kwestionariusz o kosztach bieżących poniesionych na ochronę środowiska - OŚ-29/k" [Rozporz̨qdzenie Prezesa Rady Ministrów..., 2013].

Na podstawie wyników badań prowadzonych corocznie w rocznikach statystycznych „Ochrona Środowiska”, sa publikowane dane o kosztach bieżących ochrony środowiska (w tym nakłady w gospodarstwach domowych) przez Główny Urząd Statystyczny. Dane te są prezentowane w różnych układach, według dziedzin ochrony środowiska w sektorze: publicznym, gospodarczym i sektorze usług ochrony środowiska, jak również wedlug Polskiej Klasyfikacji Działalności (PKD).

W sprawozdaniu OŚ-29/k są zawarte przede wszystkim informacje o kosztach bieżacych, poniesionych na ochronę środowiska, w postaci wielkości:

- $\quad$ kosztów związanych z funkcjonowaniem i utrzymaniem urządzeń ochrony środowiska;

- $\quad$ kosztów obsługi i utrzymania działalności związanej z ochroną środowiska (technologii, procesu, wyposażenia);

- $\quad$ kosztów kontroli, monitoringu, badań laboratoryjnych itp.;

- opłat ekologicznych;

- $\quad$ opłat usługowych (np. za oczyszczanie ścieków i wywóz odpadów).

Jest uzasadnione to, aby nie uwzględniać w ostatecznej kalkulacji poniesionych kosztów środowiskowych przychodów i oszczędności osiaganych z tytułu: funkcjonowania urządzeń ochronnych, subwencji z innych sektorów, jak również przychodów za usługi ochrony środowiska (np.: oczyszczanie ścieków, transport i unieszkodliwianie odpadów), co także ma miejsce.

W konsekwencji, za koszty bieżące ochrony środowiska brutto uważa się koszty obsługi i utrzymania działalności (technologii, procesu, wyposażenia) związanej z ochroną środowiska, których głównym celem jest: zapobieganie, zmniejszanie, unieszkodliwianie lub eliminowanie zanieczyszczeń i jakichkolwiek innych strat środowiskowych, wynikających z bieżącej działalności jednostki. Obejmują one: koszty działań własnych, w tym koszty dotyczące funkcjonowania i utrzymania urządzeń ochrony środowiska („,końca rury” i zapobiegających zanieczyszczeniom) oraz koszty działań świadczonych przez podmioty zewnętrzne, opłaty usługowe (za oczyszczanie ścieków i wywóz odpadów), opłaty ekologiczne, jak również koszty: kontroli, monitoringu, badań laboratoryjnych itp. [Ochrona Środowiska, 2012, s. 403]. Zatem, koszty bieżące ochro- 
ny środowiska netto są to koszty brutto pomniejszone o, wymienione wcześniej, przychody i oszczędności.

Ponadto, warto dodać, że w myśl przyjętej metodyki, do kosztów bieżących ochrony środowiska nie wlicza się kosztów [Ochrona Środowiska, 2012, s. 403]:

- odpisów amortyzacyjnych;

- działań związanych z bezpieczeństwem i higieną pracy;

- $\quad$ kosztów gospodarki wodnej i leśnej;

- kosztów działań związanych z ochroną.

Pewne zdumienie wywołuje to, że w świetle metodyki prezentowanej przez Główny Urząd Statystyczny w roczniku „Ochrona Środowiska”, służącej obliczaniu kosztów bieżących ochrony środowiska, nie są uwzględniane koszty odpisów amortyzacyjnych od środków trwałych (służących ochronie środowiska), tym bardziej że w formularzu sprawozdawczym OŚ-29/k („Kwestionariusz o kosztach bieżących poniesionych na ochronę środowiska”) jest przewidziana rubryka „amortyzacja”, przeznaczona do zamieszczenia kwoty z tego tytułu.

Druga wątpliwość odnosi się do kategorii opłat ekologicznych. W „Objaśnieniach do kwestionariusza o kosztach bieżących poniesionych na ochronę środowiska w 2012 roku” [Rozporzqdzenie Prezesa Rady Ministrów..., 2013] do opłat ekologicznych zalicza się jedynie następujące opłaty:

- za emisję zanieczyszczeń do powietrza;

- $\quad$ za pobór wód powierzchniowych i podziemnych;

- $\quad$ za odprowadzanie ładunków zanieczyszczeń w ściekach do wód lub do ziemi;

- za składowanie odpadów na składowisku odpadów;

- $\quad$ za nierolnicze lub nieleśne wykorzystywanie gruntów rolnych i leśnych;

- za usuwanie drzew lub krzewów;

- produktowe.

Tymczasem za opłaty ekologiczne powszechnie uważa się również [Małecki, 2012, s. 27]:

- opłaty za działalność górniczą (koncesyjne i eksploatacyjne);

- $\quad$ opłaty z tytułu użytkowania obiektów i obszarów związanych z gospodarka wodną (należności za korzystanie ze śródlądowych dróg wodnych oraz urządzeń wodnych stanowiących własność Skarbu Państwa, opłaty za oddanie w użytkowanie niektórych gruntów pokrytych wodami stanowiących własność Skarbu Państwa, opłaty za oddanie w użytkowanie obwodów rybackich, opłaty za udostępnianie danych z katastru wodnego);

- opłaty z tytułu handlu uprawnieniami do emisji;

- $\quad$ opłaty z tytułu składania wniosków o pozwolenie zintegrowane;

- opłaty za brak sieci zbierania wyeksploatowanych pojazdów;

- opłaty za substancje zubożające warstwę ozonowa;

- $\quad$ opłaty zastępcze za niewykupienie wymaganej ilości energii odnawialnej.

Warto przy tym zwrócić uwagę na to, że opłaty ekologiczne nie stanowia sensu stricto kosztów ochrony środowiska (czy też poniesionych na ochronę). Są to koszty korzystania ze środowiska (bądź też z zasobów środowiska). 
Skoro do kosztów bieżących, poniesionych na ochronę środowiska, należą opłaty ekologiczne, jakkolwiek nie są to w istocie rzeczy koszty ochrony, lecz - korzystania ze środowiska, to w konsekwencji należałoby tu również uwzględnić podatki ekologiczne, czyli: podatek akcyzowy nałożony na szkodliwe dla środowiska dobra konsumpcyjne (paliwa, energia, samochody), podatek od środków transportowych oraz podatek leśny i podatek rolny. Jest to tym bardziej uzasadnione, że wysokość kwot pochodzących z podatków ekologicznych wielokrotnie przekracza wysokość kwot z opłat ekologicznych [Małecki, 2012, s. 236-237].

Obok najważniejszego, z punktu widzenia tego artykułu sprawozdania OŚ-29/k, obowiązuje wiele formularzy sprawozdawczych, odnoszących się do finansowych aspektów ochrony i korzystania ze środowiska, a co za tym idzie, zawierających informacje dotyczace kosztów środowiskowych. W ramach „Programu badań statystyki publicznej”, prowadzonych przez Prezesa Głównego Urzędu Statystycznego, są to: Załącznik do sprawozdań F-03 (sprawozdanie o stanie i ruchu środków trwałych), SP (roczna ankieta przedsiębiorstwa) i SG-01 (statystyka gminy), związane z nakładami na środki trwałe służące ochronie środowiska i gospodarce wodnej oraz uzyskanych efektów rzeczowych. Natomiast, poza „Programem badań statystyki publicznej”, obowiązują następujące sprawozdania zawierające informacje dotyczące omawianego zakresu:

- Wykaz zawierajacy zbiorcze zestawienie informacji o zakresie korzystania ze środowiska oraz o uysokości należnych optat;

- Sprawozdanie o uysokości należnej oplaty produktowej;

- Sprawozdanie o wysokości należnej optaty produktowej dla sprzętu;

- Informacja dotyczaca bezzbiornikowego magazynowania substancji w górotworze oraz. sketadowania odpadów;

- Roczne sprawozdanie o wysokości nale żnej oplaty za brak sieci zbierania pojazdón;

- Roczne sprawozdanie o wysokości należnej optaty za substancje kontrolowane, wprowadzone po razpierws zy na terytorium Rzeçypospolitej Polskiej;

- Deklaracja o wysokości akcysy pobranej i wplaconej przez.podatnika (od energii elektrycznej, paliw i samochodón);

- Deklaracja na podatek od środków transportonych;

- Deklaracja na podatek. lésny;

- Deklaracja na podatek rolny.

Wymienione sprawozdania zawierają szczegółowe informacje odnoszące się do wielu pozycji zaliczonych do kosztów środowiskowych. Stanowią zatem element sprawozdawczości statystycznej z omawianego zakresu.

\section{Analiza kształtowania się wielkości kosztów środowiskowych w latach 2005-2010}

Nakłady na ochronę środowiska oraz koszty bieżące na ochronę środowiska są przedmiotem badań statystycznych, a ich wielkość według dziedzin ochrony środo- 
wiska jest podstawowym miernikiem działań na rzecz ochrony środowiska. Obowiązek badania nakładów środowiskowych wynika, z jednej strony, z obowiązu sprawozdawczego [Broniewicz, 2003, s. 32-43], a z drugiej strony, osiagane wyniki są podstawowym miernikiem nie tylko działalności środowiskowej, zapewniającej poprawę stanu środowiska przyrodniczego, lecz także kosztów środowiskowych.

Podstawowym wskaźnikiem, określającym względną wysokość nakładów inwestycyjnych na ochronę środowiska, jest wielkość nakładów inwestycyjnych w przeliczeniu na jednostkę PKB. W Polsce udział całkowitych nakładów na ochronę środowiska w przeliczeniu na jednostkę PKB wahał się w granicach od 3,1\% w roku 2005 do 3,5\% w roku 2010 i był niższy w porównaniu z 2000 rokiem, kiedy to wynosił 4,5\% [Ocbrona środowiska, 2009, s. 401]. Natomiast wskaźnik całkowitych nakładów na ochronę środowiska w przeliczeniu na jednego mieszkańca w latach 2005-2010 kształtował się odpowiednio na poziomie od 856,5 zł do 1227,3 zł, co stanowi wzrost o 43\%. Ponadto, należy zauważyć, iż mimo systematycznego wzrostu (o 45\%) ogólnych nakładów na ochronę środowiska w badanym okresie, w latach 2008-2009 odnotowano nieznaczny spadek zarówno udziału w PKB, jak i w przeliczeniu na jednego mieszkańca.

W przypadku nakładów na środki trwałe zaobserwowano jeszcze większy przyrost pomiędzy 2005 a 2010 rokiem, który wyniósł 69\%, przy czym w 2010 roku był zauważalny nieznaczny spadek w tym zakresie. W latach 2005-2010 średni udział w PKB kształtował się na poziomie poniżej jednego procenta i w tym okresie wzrósł o 33\%, tj. z 0,6\% w 2005 roku do 0,8\% w 2010 roku. Oznacza to, że Polska znajduje się w dalszym ciagu w okresie intensywnego inwestowania w sferę ochrony środowiska.

Poza tym, w odniesieniu do kosztów bieżących także można było zauważyć wyraźny wzrost o 49\%, niemniej jednak w roku 2008 odnotowano nieznaczny spadek w równej mierze udziału w PKB, jak i w przeliczeniu na jednego mieszkańca w stosunku do roku poprzedniego.

Podobnie jak w stosunku do ogólnych nakładów na ochronę środowiska, również wydatki gospodarstw domowych systematycznie rosły (wzrost o 34\% w latach 2005-2010), przy czym największe wahania zaobserwowano w przypadku udziału w PKB w latach 2006-2010. Wśród przyczyn tych wahań w procesie inwestycyjnym, w latach 2007-2009 można wymienić m.in. pogorszenie ogólnej koniunktury w gospodarce narodowej, spowodowane światowym kryzysem gospodarczym.

Szczegółowe dane, dotyczące nakładów na ochronę środowiska w latach 2005-2010, prezentuje tabela 1. 
TABELA. 1.

Nakłady na ochronę środowiska (nakłady na środki trwałe i koszty bieżące netto)

\begin{tabular}{|c|c|c|c|c|c|c|c|}
\hline Wyszczególnienie & 2005 & 2006 & 2007 & 2008 & 2009 & 2010 & $\begin{array}{c}\text { Dynamika } \\
2010 / 2005 \\
(2005=100)\end{array}$ \\
\hline Ogółem w mln & 32687,7 & 38593,9 & 43955,3 & 43956,0 & 46544,6 & 47286,3 & 145 \\
\hline $\begin{array}{l}\text { Udział w produkcie kra- } \\
\text { jowym brutto }(\mathrm{w} \%)\end{array}$ & 3,1 & 3,4 & 3,4 & 3,4 & 3,7 & 3,5 & 113 \\
\hline Na 1 mieszkańca (w zł) & 856,5 & 1012,3 & 1153,2 & 1152,6 & 1219,3 & 1227,3 & 143 \\
\hline \multicolumn{8}{|c|}{ Nakłady na środki trwałe } \\
\hline Ogółem (w mln zł) & 6457,8 & 7345,8 & 8321,7 & 9056,6 & 10949,4 & 10926,2 & 169 \\
\hline $\begin{array}{l}\text { Udział w produkcie kra- } \\
\text { jowym brutto (w \%) }\end{array}$ & 0,6 & 0,7 & 0,6 & 0,7 & 0,9 & 0,8 & 133 \\
\hline Na 1 mieszkańca (w zł) & 169,4 & 192,7 & 218,3 & 237,5 & 286,8 & 283,6 & 167 \\
\hline \multicolumn{8}{|l|}{ Koszty bieżące } \\
\hline Ogółem (w mln zl) & 8139,5 & 9212,7 & 11975,4 & 10982,5 & 11565,3 & 12159,6 & 149 \\
\hline $\begin{array}{l}\text { Udział w produkcie kra- } \\
\text { jowym brutto (w \%) }\end{array}$ & 0,8 & 0,8 & 0,9 & 0,8 & 0,9 & 0,9 & 113 \\
\hline Na 1 mieszkańca (w zł) & 213,6 & 241,6 & 314,2 & 288,0 & 303,0 & 315,6 & 148 \\
\hline \multicolumn{8}{|c|}{ Wydatki gospodarstw domowych } \\
\hline Ogółem (w mln zł) & 18090,4 & 22035,4 & 23658,1 & 23916,9 & 24029,9 & 24200,5 & 134 \\
\hline $\begin{array}{l}\text { Udział w produkcie kra- } \\
\text { jowym brutto (w \%) }\end{array}$ & 1,7 & 2,0 & 1,8 & 1,8 & 1,9 & 1,8 & 106 \\
\hline $\mathrm{Na} 1$ mieszkańca (w zł) & 473,6 & 578,0 & 620,7 & 627,1 & 629,5 & 628,1 & 133 \\
\hline
\end{tabular}

Źródło: obliczenia własne na podstawie: [Ochrona środowiska, 2009, s. 401; Ochrona środowiska, 2012, s. 411].

Wzrost istotnych nakładów na inwestycje służące ochronie środowiska jest związany zarówno z nadrabianiem zaległości w tej sferze w porównaniu z innymi krajami Unii Europejskiej, jak i z ciąłłym dostosowywaniem działalności do wymogów prawnych ochrony środowiska. Ogólnie stwierdza się zwiększony udział kosztów bieżących w strukturze całkowitych nakładów na ochronę środowiska, co ma odzwierciedlenie w większym zaangażowaniu funduszy ekologicznych w finansowanie przedsięwzięć proekologicznych.

Analizując strukturę nakładów według dziedzin ochrony środowiska w sektorze publicznym, gospodarczym i sektorze usług ochrony środowiska, widać również duże zróżnicowanie. W badanym okresie można zauważyć znaczący wzrost inwestycji na ochronę środowiska, za wyjątkiem obszaru dotyczącego ochrony przed promieniowaniem jonizującym, gdzie odnotowano spadek o 45\%. Należy podkreślić, iż jest to obszar o najniższych nakładach w wielkościach bezwzględnych. Dominującym obszarem pod względem przyrostu nakładów inwestycyjnych w latach 2005-2010 była ochrona różnorodności biologicznej i krajobrazu, gdzie odnotowano wzrost o 216\%. Niemniej jednak, biorąc pod uwagę wielkości bezwzględne nakładów inwestycyj- 
nych, to w 2010 roku obszar ten znajdował się na piątym miejscu. Na drugim miejscu, z osiemdziesięciotrzyprocentowym przyrostem, znalazła się gospodarka ściekowa i ochrona wód, przy czym obszar ten odznaczał się największymi nakładami w wielkościach bezwzględnych i wyniósł ponad 10 mld w 2010 roku. To oznacza, że zdecydowana większość wydatków inwestycyjnych była przeznaczana na działalność związaną z gospodarką ściekową i ochroną wód. Najmniejszy wzrost nakładów można było zaobserwować w obszarze gospodarki odpadami, ochrony gleb oraz wód podziemnych i powierzchniowych, który wyniósł w badanym okresie zaledwie 12\%. Jednakże, jeżeli chodzi o wielkości bezwzględne, obszar ten uplasował się na trzecim miejscu w 2010 roku. Ponadto, warto zanotować, iż w okresie 2008-2009 był zauważalny ogólny spadek nakładów w większości obszarów, a szczególnie w zakresie: ochrony powietrza atmosferycznego i klimatu, gospodarki odpadami, ochrony przed hałasem i wibracjami, ochrony przed promieniowaniem jonizującym oraz w zakresie pozostałej działalności związanej z ochroną środowiska, w tym także działalności badawczorozwojowej.

Proces integracyjny wymusił w Polsce dostosowanie działalności do przepisów prawnych i osiagnięcie wymaganego stanu ochrony środowiska. Większość środków inwestycyjnych jest przeznaczana na gospodarkę ściekową i ochronę wód, głównie na oczyszczalnie ścieków oraz na ochronę powietrza atmosferycznego i klimatu, jak również na gospodarkę odpadami, przy czym zwłaszcza w tym obszarze odnotowano najmniejszy wzrost nakładów inwestycyjnych w stosunku do, wyżej wymienionych, dziedzin ochrony środowiska.

Szczegółowe dane dotyczące nakładów na ochronę środowiska, według dziedzin ochrony środowiska, w latach 2005-2010 przedstawia tabela 2.

Ogólnie należy stwierdzić, iż nowe regulacje i wymagania prawne, wprowadzone w ciagu ostatnich kilku lat w Polsce, w związku z przystapieniem do Unii Europejskiej, np. w zakresie gospodarki ściekowej, prowadzą do zwiększenia nakładów na ten rodzaj działalności. Potwierdzają to także założenia docelowej struktury nakładów na ochronę środowiska, zawarte w „Programie wykonawczym do II Polityki Ekologicznej państwa na lata 2002-2010" [Program wykonawczy do II Polityki Ekologicznej..., 2002, s. 6]. 
TABELA 2.

Nakłady na ochronę środowiska (nakłady na środki trwałe i koszty bieżące netto) według dziedzin ochrony środowiska w sektorze publicznym, gospodarczym i sektorze usług ochrony środowiska (ceny stałe)

\begin{tabular}{|c|c|c|c|c|c|c|c|}
\hline Wyszczególnienie & 2005 & 2006 & 2007 & 2008 & 2009 & 2010 & $\begin{array}{c}\text { Dynamika } \\
2010 / 2005 \\
(2005=100)\end{array}$ \\
\hline Ogółem (w mln zł) & 14597,3 & 16558,6 & 20297,1 & 20039,1 & 22514,8 & 23085,8 & 158 \\
\hline $\begin{array}{l}\text { Udział w produkcie krajo- } \\
\text { wym brutto }(\mathrm{w} \%)\end{array}$ & 1,4 & 1,5 & 1,6 & 1,5 & 1,8 & 1,9 & 136 \\
\hline Na 1 mieszkańca (w zł) & 382,9 & 434,3 & 532,5 & 525,5 & 590,4 & 599,2 & 156 \\
\hline $\begin{array}{l}\text { Ochrona powietrza atmo- } \\
\text { sferycznego i klimatu }\end{array}$ & 3069,2 & 3750,9 & 4065,4 & 4372,3 & 4255,3 & 4888,8 & 159 \\
\hline $\begin{array}{l}\text { Gospodarka ściekowa } \\
\text { i ochrona wód }\end{array}$ & 5712,3 & 6180,3 & 8411,4 & 9119,5 & 10655,7 & 10455,1 & 183 \\
\hline $\begin{array}{l}\text { Gospodarka odpadami, } \\
\text { ochrona gleb i wód pod- } \\
\text { ziemnych i powierzchnio- } \\
\text { wych }\end{array}$ & 3630,4 & 3890,8 & 4671,4 & 3333,2 & 3961,4 & 4072,5 & 112 \\
\hline $\begin{array}{l}\text { Ochrona różnorodności } \\
\text { biologicznej i krajobrazu }\end{array}$ & 354,1 & 337,2 & 955,3 & 1008,2 & 1103,4 & 1118,6 & 316 \\
\hline $\begin{array}{l}\text { Ochrona przed hałasem } \\
\text { i wibracjami }\end{array}$ & 168,0 & 132,9 & 150,2 & 230,2 & 142,4 & 207,9 & 124 \\
\hline $\begin{array}{l}\text { Ochrona przed promienio- } \\
\text { waniem jonizującym }\end{array}$ & 9,9 & 8,2 & 8,4 & 10,7 & 5,8 & 5,4 & 55 \\
\hline $\begin{array}{l}\text { Pozostała działalność zwia- } \\
\text { zana z ochroną środowiska } \\
\text { (łącznie z działalnością ba- } \\
\text { dawczo-rozwojowa) }\end{array}$ & 1653,4 & 2258,1 & 2035,2 & 1964,9 & 2390,7 & 2337,4 & 141 \\
\hline
\end{tabular}

Źródło: obliczenia własne na podstawie: [Ochrona środowiska, 2009, s. 401; Ocbrona środowiska, 2012, s. 411].

\section{Przewidywane zmiany w statystyce kosztów środowiskowych w świetle wymogów Eurostatu}

Kraje członkowskie Unii Europejskiej, w tym Polska, zobowiazane są do wykonywania rachunków ekonomicznych środowiska (EEA, ang. Environmental Economic Accounts). Sporząazanie rachunków środowiska $\mathrm{w}$ procesach modelowania i prognozowania zjawisk ma istotne znaczenie, zarówno do celów opracowywania propozycji politycznych, jak i do celów sprawozdawczości dotyczącej realizacji polityki i jej skutków. Obowiązek wykonywania takich rachunków wynika z rozporządzenia Parlamentu Europejskiego i Rady [Ro:porzadzenie Parlamentu Europejskiego..., 2011]. Wprowadziło ono na kraje członkowskie Unii Europejskiej obowiązek sprawozdawczy w zakresie sporządzania tych rachunków i przekazywania danych sprawozdawczych do Komisji Europejskiej (Eurostatu). 
W świetle wspomnianego rozporządzenia rachunki ekonomiczne środowiska maja być sporządzane w podziale na trzy moduły:

- modul rachunków emisji do powietrza;

- modul podatków związanych ze środowiskiem według rodzajów działalności gospodarczej;

- moduł ogólnogospodarczych rachunków przepływów materiałowych.

Jednak obecnie trwaja prace nad rozszerzeniem tych działań, między innymi o moduł kosztów środowiskowych, a precyzyjniej - wydatków na ochrone środowiska. Projekt rozporzqdzenia Parlamentu Europejskiego i Rady w tej sprawie został przygotowany [Wniosek rozporzqdzenia Parlamentu Europejskiego..., 2011] i obecnie jest poddawany konsultacjom, w których uczestniczą krajowe podmioty, dostarczające danych w zakresie statystyk i rachunków dotyczących środowiska, jak też użytkownicy tych danych.

Wprowadzenie w życie realizacji sprawozdawczości statystycznej na potrzeby modułu podatków związanych ze środowiskiem pokrywa się w pewnej części z dotychczas prowadzoną w Polsce sprawozdawczością wiążącą się z kosztami bieżącymi ochrony środowiska. Jak bowiem wcześniej wspomniano, do kosztów tych zalicza się opłaty za korzystanie ze środowiska i część innych obowiązujących opłat ekologicznych.

Prace nad sprawozdawczością zawierająca moduł podatków obejmujących środowisko są zaawansowane. W ramach tych prac sporządzono listę podatków związanych ze środowiskiem, jak również przyjęto metodykę rozszacowywania danych ilościowych na wymagane grupy zgodnie z NACE (fr. Nomenclature statistique des Activités économiques dans la Communauté Européenne). W początkowych miesiącach 2014 roku ma nastapić pierwsza pilotażowa transmisja danych sprawozdawczych do Eurostatu za okres 2008-2010.

Wejście w życie nowego rozporządzenia Parlamentu Europejskiego i Rady docelowo będzie skutkować znaczną modyfikacją, obecnie obowiązującej, procedury sprawozdawczości statystycznej, prowadzonej w Polsce w zakresie kosztów bieżących ochrony środowiska. Musi ona zostać poprzedzona licznymi pracami przygotowawczymi i konsultacjami zainteresowanych podmiotów.

Zgodnie $z$ projektem rozporządzenia zmieniającego dotychczasowe rozporządzenie w sprawie europejskich rachunków ekonomicznych środowiska, wydatki na ochronę środowiska oznaczaja: zasoby gospodarcze przeznaczane na ochrone śodowisk a przez jednostki bedace rezydentami [Wniosek rozporzqdzenia Parlamentu Europejskiego ..., 2011, s. 5]. Na ochronę środowiska składają się przy tym wszystkie rodzaje działalności i działań, których głównym zadaniem jest ograniczanie oraz eliminacja zanieczyszczeń i wszelkich innych form degradacji środowiska, a także zapobieganie tym zjawiskom. Zalicza się tu również środki podejmowane w celu odnowy zdegradowanego środowiska. Istotne jest jednocześnie to, że działania, które są wprawdzie korzystne dla środowiska, ale zmierzają przede wszystkim do spełnienia wymagań technicznych lub wymogów wewnętrznych w zakresie higieny i bezpieczeństwa, nie są tu ujęte.

W świetle zapisów, wspomnianego projektu rozporządzenia zmieniającego dotychczasowe rozporządzenie w sprawie europejskich rachunków ekonomicznych środowiska, krajowe wydatki na ochronę środowiska definiuje się jako: sume wykoraystania ustug zwiazanych zochrona środowiska przezjednostki będace rezydentami, nakladów brutto na 
środki trwate przeznaczonych na dziatalność zwiazana z. ochronq środowiska oraz transferón zwiqzanych z ochrona środowiska, które nie stanowiq odpowiedników powyższych posycji, pomniejszona o finansowanie przez zagranice [Wniosek rozporzadzenia Parlamentu Europejskiego..., 2011, s. 7].

W ujęciu sektorowym, zgodnie z Europejskim Systemem Rachunków (ESA, ang. European System of Accounts), rachunki wydatków na ochronę środowiska obejmują: instytucje rządowe i samorządowe ( $\mathrm{w}$ tym instytucje niekomercyjne, działające na rzecz gospodarstw domowych), przedsiębiorstwa i instytucje finansowe, gospodarstwa domowe oraz sektor „zagranica” (transfery związane z ochroną środowiska). Sektory instytucjonalne występują zarówno jako świadczący usługi związane z ochroną środowiska, jak i konsumenci tych usług.

Według projektu rozporządzenia zmieniającego dotychczasowe rozporządzenie w sprawie europejskich rachunków ekonomicznych środowiska, krajowe dane sprawozdawcze, dotyczące wydatków na ochronę środowiska, mają być zestawiane i przekazywane w cyklu rocznym. Pierwszy transfer danych ma nastąić w ciagu dwóch lat od wejścia w życie rozporządzenia zmieniającego dotychczasowe rozporządzenie w sprawie europejskich rachunków ekonomicznych środowiska. W ramach pierwszego przekazania danych o wydatkach na ochronę środowiska zostaną ujęte dane roczne z okresu od 2013 roku do roku wejścia w życie projektu tego rozporządzenia.

\section{Podsumowanie}

Nakłady na ochronę środowiska są przedmiotem badań statystycznych podobnie w Polsce, jak i w Unii Europejskiej. Stanowią one nie tylko jeden z podstawowych wskaźników określających zakres spełniania przyjętych wymogów prawnych w dziedzinie ochrony środowiska, lecz także sa podstawowym miernikiem kosztów środowiskowych.

Analizując wielkości względne (udział w PKB oraz w przeliczeniu na jednego mieszkańca) i bezwzględne (całkowite nakłady w milionach), widać ogólnie wzrost inwestycji środowiskowych, a szczególnie nakłady na środki trwałe, gdzie w latach 2005-2010 odnotowano wzrost o 69\%.

W strukturze wydatkowania środków finansowych dominuje gospodarka wodno-ściekowa, która odznaczała się najwyższym udziałem w nakładach na ochronę środowiska ogółem (45\% w 2010 roku). Mimo to, największy średni wzrost nakładów inwestycyjnych odnotowano w zakresie ochrony różnorodności biologicznej i krajobrazu, przy czym kategoria ta stanowiła jedynie 4,8\% ogólnych nakładów.

Dotychczas prowadzona w Polsce sprawozdawczość statystyczna w zakresie kosztów środowiskowych, zgodnie $\mathrm{z}$ nowymi wymogami Eurostatu, ulegnie w najbliższym czasie zmianie. Będzie to skutkować znaczną modyfikacja, obecnie obowiązującej, procedury sprawozdawczości statystycznej dotyczącej kosztów bieżących ochrony środowiska. Jednocześnie stanie się wyzwaniem dla różnych podmiotów korzystajacych z zasobów środowiska i objętych obowiązkiem sporządzania sprawozdań w zakresie wielkości ponoszonych kosztów środowiskowych, w szczególności będzie to dotyczyć przedsiębiorstw. 


\section{Literatura}

Broniewicz E. 2003 Metodykea badania naktadów inwestycyjnych na ochrone środowiska w Unii Europejskiej i Polsce, „Ekonomia i Środowisko”, nr 1(23).

Environmental expenditure statistics 2005, Industry Data Collection Handbook, Office for Official Publications of the European Communities, Luxembourg, dokument elektroniczny, tryb dostępu: [http://epp.eurostat.ec.europa.eu/cache/ITY_ OFFPUB/KS-EC-05-002/EN/KS-EC-05-002-EN.PDF, data wejścia: 12.11.2013].

Famielec J., Broniewicz E. 2006 Odzwierciedlenie aspektów ochrony środowiska w sprawozdawczości matych $i$ średnich pręedsiębiorcón w świetle ustany o rachunkowości, Opracowanie na zlecenie Ministerstwa Gospodarki, Białystok - Kraków.

Hellich E., Klonowska M. 2007 Rachunek kosztón ochrony środowiska, [w:] Zarzqdzanie kosz̨tami jakości, logistyki, innowacii, ochrony środowiska a rachunkowość finansowa, A. Karmańska (red.), Wydawnictwo Difin, Warszawa.

Leiffaden Betriebliches Umweltkostenmanagement 2003, (Hrsg.) Bundesumweltministerium, Umweltbundesamt, Berlin, dokument elektroniczny, tryb dostępu: [http://www.umweltbundesamt.de/sites/default/files/medien/publikation/lon g/2292.pdf, data wejścia: 12.11.2013].

Małecki P.P. 2012 System optat i podatków ekologicznych w Polsce na tle rozwiqzan w krajach OECD, Wydawnictwo Uniwersytetu Ekonomicznego w Krakowie, Kraków.

Micherda B. 2002 Podstany rachunkowości, Wydawnictwo Akademii Ekonomicznej w Krakowie, Kraków.

Ochrona Środowiska 2009, GUS, Warszawa.

Ochrona Środowiska 2011, GUS, Warszawa.

Ochrona Środowiska 2012, GUS, Warszawa.

Program nykonawncsy do II Politykei Ekologicznej Państwa na lata 2002-2010 2002, Rada Ministrów, Warszawa, dokument elektroniczny, tryb dostępu: [https://www.mos.gov.pl/ g2/big/2009_04/8e398d38e6e726efcc07581 f8b410c48.pdf, data wejścia: 12.11.2013].

Ro:porzadzenie Parlamentu Europejskiego i Rady (UE) nr 691/2011 z dnia 6 lipca 2011 roku w sprawie europejskich rachunkón ekonomicznych środowiska, Dz. U. L 192 z 22.07.2011.

Rozporzadzenie Prezesa Rady Ministrón z. dnia 20 grudnia 2012 roku zmieniajace rozporzqdzenie w sprawie okereślenia wzorów formularay sprawozdawcsych, objaśnień co do sposobu ich uypetniania oraz wrorón kwestionariuszy $i$ ankiet statystycznych stosowanych $w$ badaniach statystycznych, ustalonych w programie badan statystycznych statystyki publicznej na rok 2012, Dz. U., 2013, Nr 0, poz. 130.

Stępień M. 2003 Rachunek kosztón ochrony środowiska, [w:] Racbunkowość ekologiczna przestanki i możliwości jej zastosowania w systemie sprawozdawczości GUS w Polsce, J. Famielec (red.), Wydawnictwo Akademii Ekonomicznej w Krakowie, Kraków.

Ustawa z dnia 27 kwietnia 2001 roku Prawo ochrony środowiska, Dz. U., 2008 rok, $\mathrm{Nr} 25$, poz. 150, z późn. zm.

Ustawa z dnia 29 czerwca 1995 roku o statystyce publicznej, Dz. U., 1995, Nr 88, poz. 439 z późn. zm. 
Ustawa z dnia 29 wrzésnia 1994 roku o rachunkowości, Dz. U., 2013, Nr 0, poz. 330 z późn. $\mathrm{zm}$.

Wniosek rozporzadzenia Parlamentu Europejskiego i Rady zmieniajacy roaporzadzenie (UE) nr 691/2011 w sprawie europejskich rachunkón ekonomicznych środowiska, COM (2013) 247 final z 2.05.2011. 